Biotechnology Research Unit,

Animal Reproduction Research Institute, Giza, Egypt

\title{
EVALUATION OF CONVENTIONAL PCR ASSAY IN COMPARISON TO REAL-TIME PCR ASSAY FOR DETECTION OF BOVINE HERPESVIRUS-1 IN BOVINE SEMEN AND SEMINAL PLASMA
}

(With One Table and 6 Figures)

\author{
By \\ SAMAH F. DARWISH and A.S. AMIN \\ (Received at 13/10/2010)
}

تقييم إختبار تفاعل البلمرة المتسلسل التقليلى مقارنة بإختبار تفاعل البلمرة

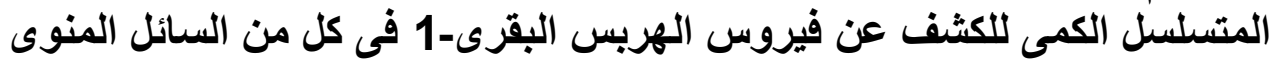
وبلازما السنائل المنوى البريق البرى

$$
\text { سعاح فكرى درويش ، عادل سبي أمين }
$$

الهدف من هذه الدراسة هو تقييم حساسية إختبار تفاعل البلمرة المتسلسل التقلبدى مقارنةً بإختبار

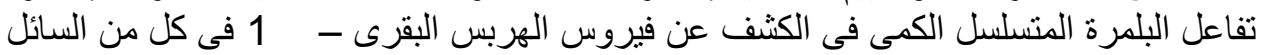

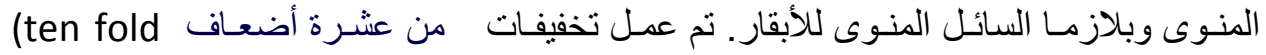

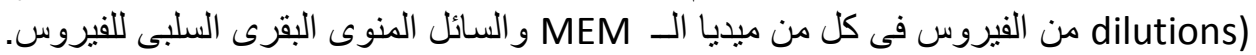

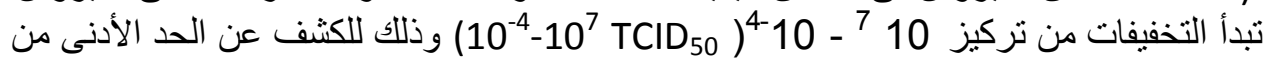

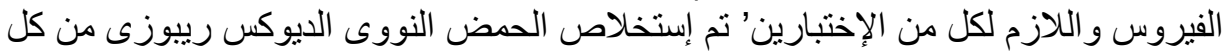

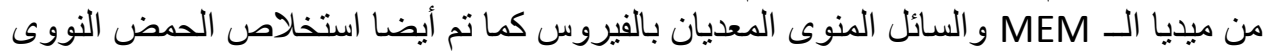

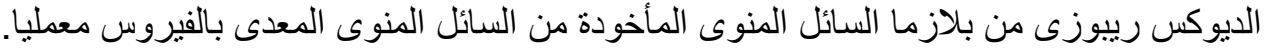

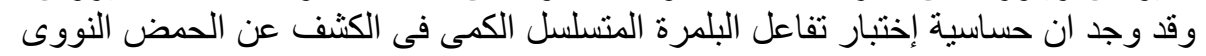

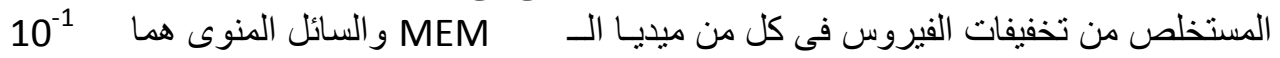

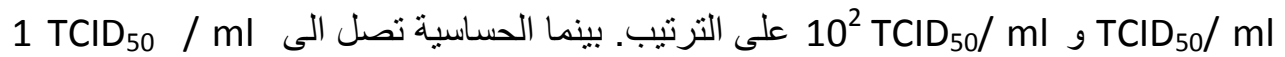

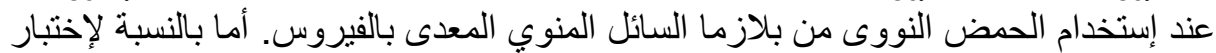
تفاعل البلمرة المتسلسل التقليدى فقد كانت الحساسية هيى 1TCID 10 TCID 50 ml و عند إستخدام

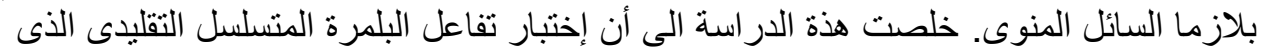

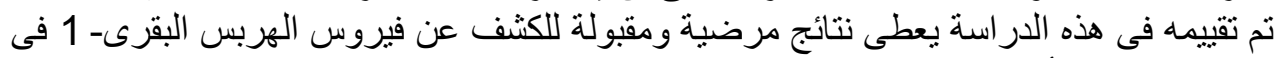

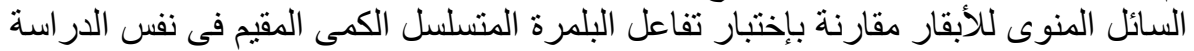

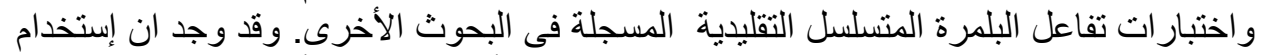

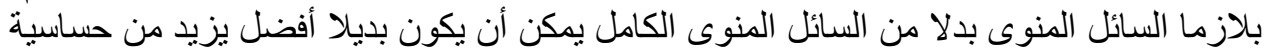

\section{SUMMARY}

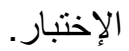


The aim of this study was to evaluate the sensitivity of conventional Polymerase Chain Reaction (PCR) assay in comparison to real time PCR assays for detection of BoHV-1 in bovine semen and seminal plasma. Tenfold serial dilutions of BoHV-1 strain were prepared in one ml aliquots of both minimal essential medium (MEM) and negative bovine semen. The dilutions started from $10^{7 \text { to }} 10^{-4}$ to detect detection limits of both PCR and real time PCR assays. Detection limits of real time PCR assay were $10^{-1}$ $\mathrm{TCID}_{50} / \mathrm{ml}$ and $10^{2} \mathrm{TCID}_{50} / \mathrm{ml}$ when PCR performed on viral DNA extracted from tenfold dilutions of BoHV-1 in MEM and artificially spiked semen, respectively. When seminal plasma of the same dilutions of spiked semen was used for DNA extraction, the PCR detection limit became 1 $\mathrm{TCID}_{50} / \mathrm{ml}$. Considering conventional PCR, detection limits were 1 TCID50/ml when PCR performed on viral DNA extracted from tenfold dilutions of BoHV-1 in MEM and artificially spiked semen as shown by the presence of a DNA band of the expected size on ethidium bromidestained agarose gels, respectively. On the other hand, the PCR detection limit was $10 \mathrm{TCID}_{50} / \mathrm{ml}$ when seminal plasma of the same dilutions of spiked semen was used. In conclusion, conventional PCR assay performed in this study provide a satisfactory results for detection of BoHV-1 in bovine semen in comparison to real time PCR and other reported PCR assays. Moreover, the use of seminal plasma instead of whole semen can be better alternative increasing the sensitivity of detection.

Key words: Bovine herpesvirus-1, BHV-1, Bovine semen, seminal plasma, PCR, Real-time PCR real time PCR assay.

\section{INTRODUCTION}

The bovine herpesvirus 1 (BoHV-1) belongs to the Herpesviridae family, subfamily alpha herpesvirinae, genus varicella virus. BoHV-1 is distributed worldwide which causes infectious bovine rhinotracheitis, (IBR), infectious pustular vulvovaginitis (IPV) and balanoposthitis (IBP) (Straub, 1991; Thiry et al., 2006 and Muylkens et al., 2007). Cattle are the principal hosts; however, the virus has been reported in swine, goats, camels, buffaloes and wild ruminants, which are considered as reservoirs (Straub, 1991; Scicluna et al., 2010). BHV-1 related-diseases complex accounts for huge economic losses due to reduced milk production and dropped feed efficiency, induced infertility, abortion, neonatal mortality, and reduced conception (Gibbs and Rweyemamu, 1977 and Miller, 1991). In Egypt, BHV-1 infection represents one of the most important 
economical problems in dairy farms affecting fertility (Mohsen et al., 1980; Ibrahim et al., 2001; El-Kholy, 2005 and Abd El-Hafeiz et al., 2010).

In BHV-1 infections in genital tract of bulls, BoHV-1 replicates in the mucosa of the prepuce, penis and possibly in the distal part of the urethra causing decreased semen quality, orchitis and seminal vesiculitis (Muylkens et al., 2007 and Mahony, 2010). Continuous discharge and persistent lesions in the penis are observed in bulls affected by the virus. Semen is most likely contaminated during ejaculation by virus that is shed from the infected mucosa (Elazhary et al., 1980). Natural service or infected semen in artificial insemination centers and contaminated milking machines are implicated in the IPV transmission most commonly observed in diary cows. Swollen and exudating labia vulvae, necrotic ulcers and formation of pustules in the vestibular mucosa, with painful and frequent urination, is described. It is widely accepted that conditions under which semen is frozen and preserved are conductive to maintaining viral infectivity (Chapman, 1979). As semen is widely distributed by the artificial insemination industry, the epidemiological risks of spreading BHV-1 infection are immediately apparent (Drew et al., 1987).

After acute infection, the virus can enter neural cells and establish a latent infection in sensory ganglia (Ackermann and Wyler, 1984 and Pastoret et al., 1984). The latent virus can be reactivated both by stressful conditions and/or administration of glucocorticoids (Thiry et al., 1984 \& 2006 and Wyler et al., 1989). BoHV-1 infected seronegative as well as seropositive bulls may shed virus intermittently in their semen long after the primary infection (Dennett et al., 1976; Ackermann and Wyler, 1984 and Office International des Epizooties, OIE, 2004). Therefore, cattle infected with BoHV-1 are regarded as lifelong carriers and potential shedders of the virus.

As BHV-1 infection is of significance to international bovine semen trade, rapid, sensitive and reliable tests for virus detection are crucial. Currently used methods for BoHV-1 detection in semen include virus isolation using cell cultures of bovine origin (OIE, 2004) and molecular techniques. Virus isolation by cell culture presents several disadvantages: it is of relatively low sensitivity because semen, raw or extended, is routinely diluted to reduce cytotoxicity and over-dilution of semen does not permit the detection of viable virus on cell culture (Schultz et al., 1982 and Weiblen et al., 1992). In addition to, the isolation method is quite timeconsuming (Weiblen et al., 1992). Different molecular assays (conventional and real-time PCR assays) have been developed to detect BoHV-1 DNA in fresh and extended semen (Wiedmann et al., 1993; 
Vilcek et al., 1994; Van Engelenburge et al., 1995; Masri et al., 1996; Wagter et al., 1996; Amin and Ibrahim, 1998; Rocha et al., 1998; Smits et al., 2000 and Wang et al., 2007). Conventional PCR has been reported to be more sensitive, specific and rapid tool for the detection of viruses than virus isolation methods. It required $4-8 \mathrm{~h}$ to reach a diagnosis. It has been reported to be more sensitive and much more rapid than virus isolation (Van Engelenburge et al., 1993, 1995 and Amin and Ibrahim, 1998). However, a disadvantage of the conventional PCR is that it can not distinguish non-specific products of the same size from the true products since the products are detected by gel electrophoresis. Real-time PCR assay has many advantages over conventional PCR, including speed (within 1.5$3 \mathrm{~h}$ ), quantitative measurement, higher sensitivity, higher specificity, easy standardization and no post-amplification manipulation is needed. This significantly minimizes the risk of cross contamination. In 2007, Wang et al., reported their real time PCR assay as rapid and sensitive test for detection of BoHV-1. Later on, The Office International des Epizooties (OIE), 2008 reported their real time assay as a prescribed test for international trade for detection of BoHV-1 in bovine semen. Although BoHV-1 present mainly free in seminal plasma (Van Engelenburge et al., 1995), according to the available data, there is no publication about application of real-time PCR for detection of BoHV1 in seminal plasma.

As facility required for performing a real time PCR assay is so expensive and not available in many laboratories especially in developing countries, the aim of this study was to evaluate the sensitivity of conventional PCR assay utilizing the same primers used in the prescribed real time PCR assay in comparison to their sensitivity in real time PCR assay for detection of BoHV-1 in bovine semen and seminal plasma.

\section{MATERIALS and METHODS}

\section{Virus strain:}

BoHV-1 (Colorado strain) was used in this study as positive control and for inoculation of MEM and bovine semen to establish PCR assays. It was kindly obtained from Virology department, Faculty of Veterinary Medicine, Cairo University. The virus titer was $10^{8} \mathrm{TCID}_{50} / \mathrm{ml}$.

\section{Semen samples:}

Three negative semen samples were obtained from bulls from BoHV-1 free private farm. Samples were transported to the laboratory of Biotechnology Research Unit, Animal Reproduction Research Institute. Two of them were experimentally spiked with the virus in ten fold serial 
dilutions. The other one was used as negative control to monitor the quality of $\mathrm{PCR}$ reactions.

\section{Preparation of BoHV-1 tenfold serial dilutions:}

Tenfold serial dilutions of BoHV-1 strain were prepared in one $\mathrm{ml}$ aliquots of both MEM and negative bovine semen $(n=2)$. The dilutions started from $10^{7 \text { to }} 10^{-4}$ to detect detection limits of both PCR and real time PCR assays. Spiked MEM and semen samples were submitted for DNA extraction. Also, seminal plasma from the spiked semen samples was also subjected to DNA extraction.

\section{Isolation of DNA:}

The method for extraction of DNA was essentially according to Wiedmann et al. (1993) with the modification of Wang et al. (2007). In brief, $10 \mu 1$ of MEM, semen or seminal plasma samples were added to $100 \mu 1$ of Chelex 100 (Sigma) (10\%, w/v, in sterile, distilled water), 11.5 $\mu 1$ of $10 \mathrm{mg} / \mathrm{ml}$, proteinase K (Sigma), $7.5 \mu \mathrm{l}$ of 1M DTT (Sigma) and $90 \mu 1$ sterile distilled water. Each sample mixture was mixed gently and incubated at $56^{\circ} \mathrm{C}$ for $30 \mathrm{~min}$. After vortexing for 10 seconds, each sample was boiled for $8 \mathrm{~min}$. After centrifugation at $10,000 \times \mathrm{g}$ for $3 \mathrm{~min}$, the supernatant containing DNA was used directly or stored at $-20 \circ \mathrm{C}$ for future use. DNA isolation from cultured viruses was also carried out using the above mentioned method.

\section{Primers and probe:}

The primers and probe reported by Wang et al. (2007) were used for PCR amplification and detection. All oligonucleotides were synthesized in Bio Basic Inc. (Canada). The sequences of primers and probe are: $\mathrm{gB}-\mathrm{F}$ 5' TGT GGA CCT AAA CCT CAC GGT 3', gB-R 5'GTA GTC GAG CAG ACC CGT GTC 3' and Probe 5'FAM-AGG ACC GCG AGT TCT TGC CGC -TAMRA 3'.

\section{Conventional Polymerase Chain Reaction (PCR):}

Conventional PCR assay was performed utilizing the same primers previously used in the real time PCR assay (Wang et al., 2007). A number of experiments were performed to optimize the PCR protocol, including concentration of reagents and PCR cycling parameters. The optimized PCR assay was finally established using a total volume of $25 \mu$ reaction mixtures contained $5 \mu \mathrm{l}$ of DNA as template, $20 \mathrm{pmol}$ of each primer and 1X of PCR master mix (Taq Master/High yield, Jena Bioscience). The amplification cycles were carried out in a PT-100 Thermocycler (MJ Research, USA). Reaction conditions were optimized to be $95^{\circ} \mathrm{C}$ for $4 \mathrm{~min}$. as initial denaturation, followed by 35 cycles of $95^{\circ} \mathrm{C}$ for 45 seconds, $60^{\circ} \mathrm{C}$ for 45 seconds and $72{ }^{\circ} \mathrm{C}$ for 60 seconds. A final extension step at $72^{\circ} \mathrm{C}$ for 10 min. was followed. Positive DNA isolated from BoHV-1 and negative 
control (no template) were included in each PCR run to ensure no cross contamination or amplification failure due to presence of inhibitors. All tests were repeated twice to ensure reproducibility of the PCR assays. Amplification products were electrophorezed in $1.5 \%$ agarose gel containing $0.5 \mathrm{X} \mathrm{TBE}$ at 70 volts for $60 \mathrm{~min}$. and visualized under ultraviolet light. To assure that the amplification products were of the expected size, a 100 bp DNA ladder was run simultaneously as a marker. Presence of 96 bp DNA fragment indicated the presence of BoHV-1 DNA in the samples.

\section{Real Time PCR:}

Real-time amplification of the BoHV-1 DNA was performed according to Wang et al. (2007) and OIE (2008). Briefly, real-time PCR was carried out using the ABsolute ${ }^{\mathrm{TM}}$ QPCR Mix, Thermo Scientific, ABgene, UK, $180 \mathrm{~nm}$ of each primer, $120 \mathrm{~nm}$ of the probe and finally $5 \mu 1$ of template DNA. The real-time PCR was carried out in a Rotor Gene 6000 real time detection system (Corbett Research, Australia). The PCR cycling parameters were initial activation step for the DNA polymerase at $95^{\circ} \mathrm{C}$ for $15 \mathrm{~min}$ followed by 45 cycles of $15 \mathrm{~s}$ at $95^{\circ} \mathrm{C}, 45 \mathrm{~s}$ of $60^{\circ} \mathrm{C}$. From each amplification plot, a threshold cycle (Ct.) value was calculated representing the PCR cycle number at which the reporter dye fluorescence was detectable above an arbitrary threshold. The threshold was set at a level that was significantly higher than that of background. Samples were considered to be positive when its fluorescence exceeds the threshold and Ct. Value was less than or equal to 45. Negative samples have no Ct. Each run included both positive and negative (no DNA template) controls. All PCR experiments were repeated twice to ensure the reproducibility of the assays

\section{RESULTS}

Preliminary tests were performed with DNA extracted from BoHV1 strain as positive control. Many trials were performed to optimize the PCR reaction components and cycling parameters. A clear $96 \mathrm{bp}$ band was readily observed with BoHV-1 DNA using $\mathrm{gB}$ forward and $\mathrm{gB}$ reverse primers. The limit of detection of both conventional and real time PCR assays was determined by testing DNA extracted from $10 \mu \mathrm{l}$ of tenfold serial dilutions of BoHV-1 in ml of both MEM and spiked semen samples. Also, it was tested on DNA extracted from $10 \mu \mathrm{l}$ of seminal plasma obtained after centrifugation of the same serial dilutions of semen. The tenfold serial dilution covered a range of $10^{7}$ to $10^{-4} \mathrm{TCID}_{50} / \mathrm{ml}$. Positive PCR products were detected covering a range from $10^{7}$ to 1 TCID50/ml 
when PCR performed on viral DNA extracted from tenfold dilutions of BoHV-1 in MEM and artificially spiked semen as shown by the presence of a DNA band of the expected size on ethidium bromide-stained agarose gels (Fig. 1 and 2) respectively. When seminal plasma of the same dilutions of spiked semen was used for DNA extraction, the PCR detection limit was $10^{1} \mathrm{TCID}_{50} / \mathrm{ml}$ as shown by the presence of a DNA band of the expected size on the ethidium bromide-stained agarose gels (Fig. 3).

Detection limits of real time PCR assays were $10^{-1} \mathrm{TCID}_{50} / \mathrm{ml}$ and $10^{2} \mathrm{TCID}_{50} / \mathrm{ml}$ when PCR performed on viral DNA extracted from tenfold dilutions of BoHV-1 in MEM and artificially spiked semen respectively (Fig. 4 and 5). When seminal plasma of the same dilutions of spiked semen was used for DNA extraction, the PCR detection limit became $1 \mathrm{TCID}_{50} /$ ml (Fig. 6). All results of the PCR experiments were reproducible when performed twice. Comparison between detection limit of both real time and conventional PCR assays for detection of BoHV-1 DNA in experimentally spiked samples are shown in Table (1).

Table 1: Comparison between real time and conventional PCR for detection of BoHV-1 DNA in different spiked samples

\begin{tabular}{|l|l|l|}
\hline \multirow{2}{*}{ Type of sample } & \multicolumn{2}{|c|}{ Detection limit } \\
\cline { 2 - 3 } & Real time PCR & Conventional PCR \\
\hline MEM & $10^{-1} \mathrm{TCID}_{50} / \mathrm{ml}$ & $1 \mathrm{TCID}_{50} / \mathrm{ml}$ \\
\hline Semen & $10^{2} \mathrm{TCID}_{50} / \mathrm{ml}$ & $1 \mathrm{TCID}_{50} / \mathrm{ml}$ \\
\hline Seminal plasma & $1 \mathrm{TCID}_{50} / \mathrm{ml}$ & $10^{1} \mathrm{TCID}_{50} / \mathrm{ml}$ \\
\hline
\end{tabular}

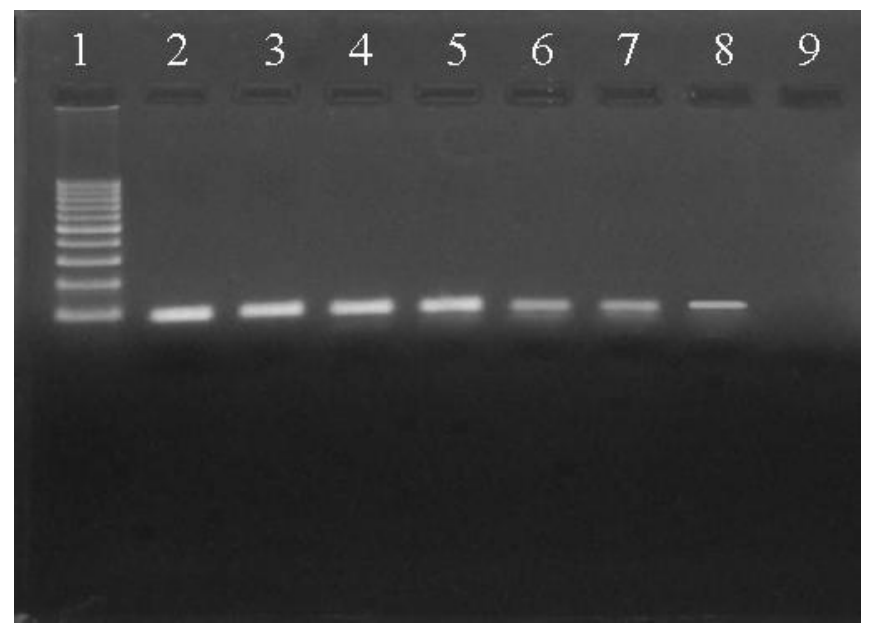

Fig. 1: PCR amplification products of BoHV-1 tenfold serial dilutions in MEM. Lane 1, 100bp ladder DNA marker. Lanes 2-8, serial dilution of BoHv-1 starting from $10^{6}$ to $1 \mathrm{TCID}_{50}$ per ml of MEM. Lane 9, negative control. 


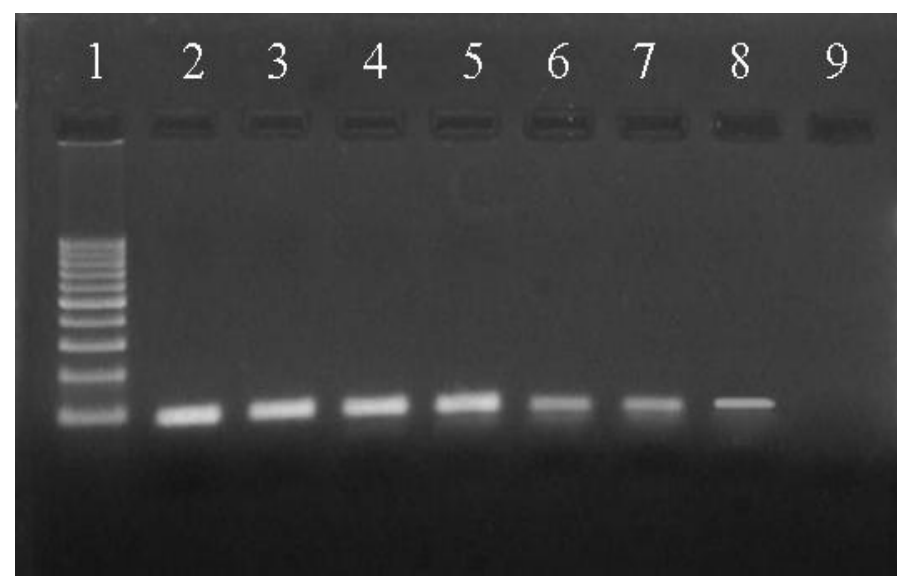

Fig. 2: PCR amplification products of BoHV-1 in tenfold serial dilution in bovine semen. Lane 1, 100bp ladder DNA marker. Lanes 2-8, serial dilution of BoHV-1 starting from $10^{6}$ to $1 \mathrm{TCID}_{50}$ per $\mathrm{ml}$ of semen. Lane 9 , negative control.

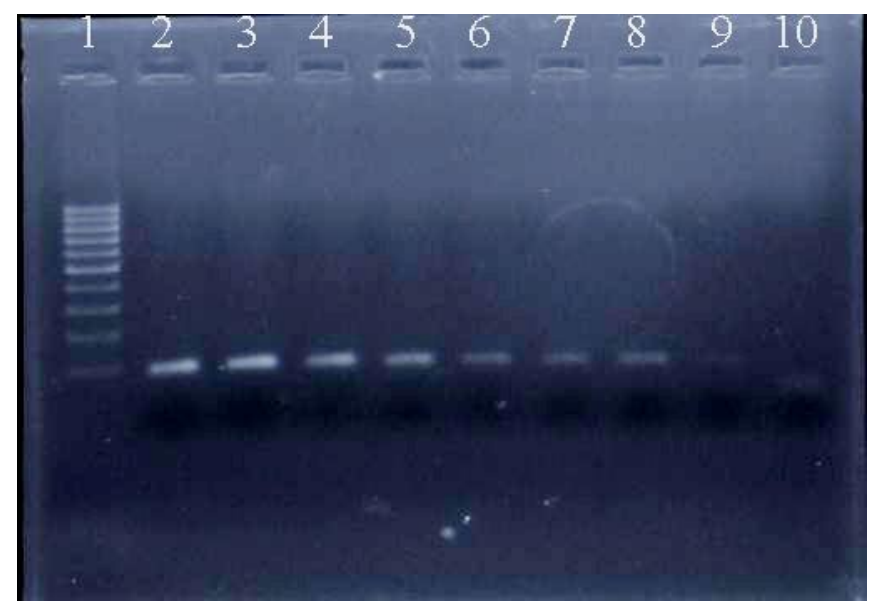

Fig. 3: PCR amplification products of BoHV-1 in seminal plasma of tenfold serial dilution in semen. Lane 1, 100bp ladder DNA marker. Lanes 2-9, serial dilution of BoHV-1 starting from $10^{7}$ to $1 \mathrm{TCID}_{50}$ per ml of semen Lane 10 , negative control. 


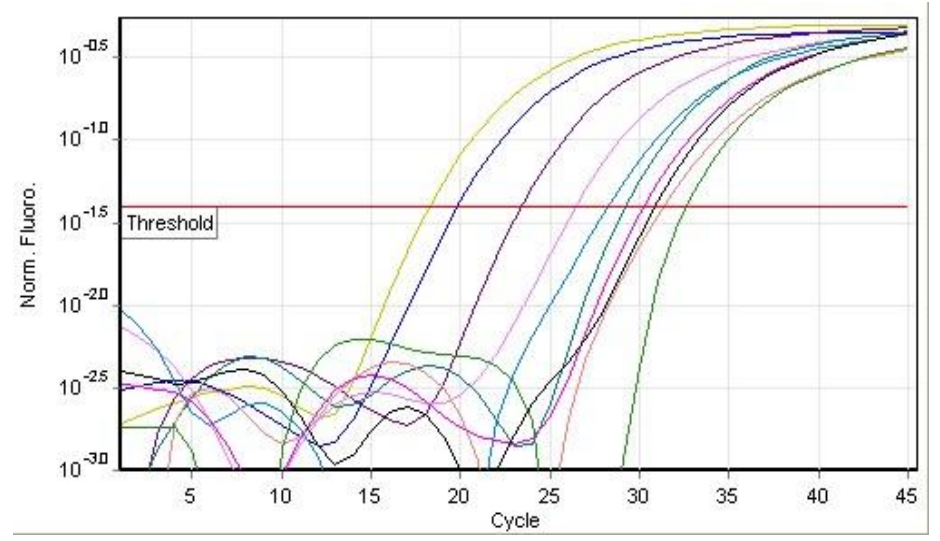

Fig. 4: Raw data of real time PCR of BoHV-1 tenfold serial dilution in MEM

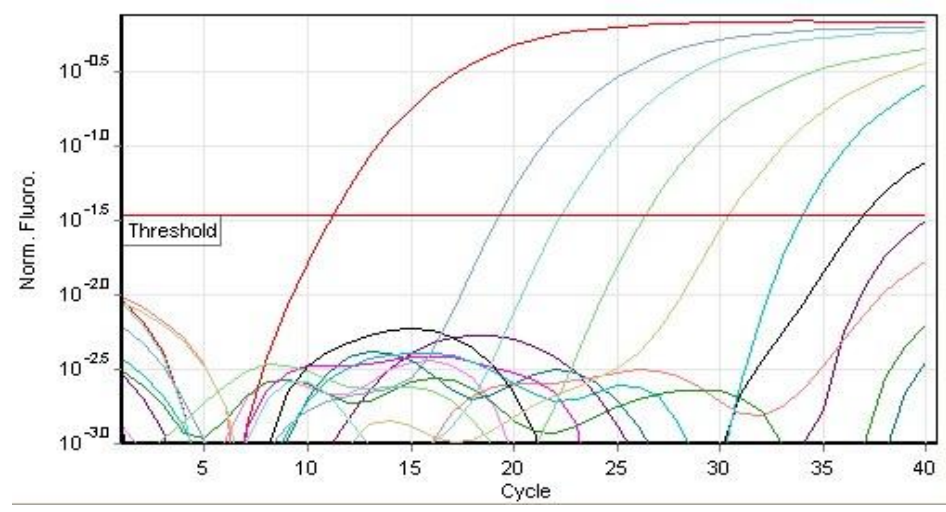

Fig. 5: Raw data of real time PCR of BoHV-1 tenfold serial dilution in semen

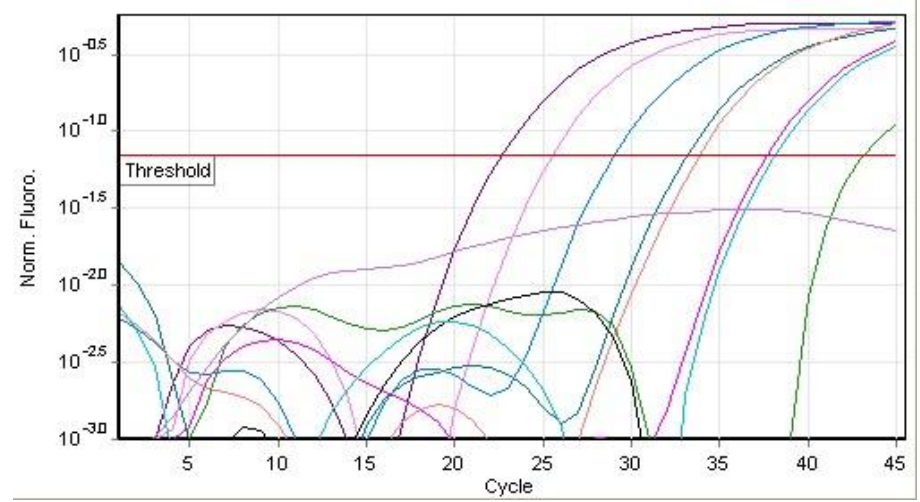

Fig. 6: Raw data of real time PCR of BoHV-1 tenfold serial dilution in seminal plasma 


\section{DISCUSSION}

BHV-1 is one of the major infectious agents which can be transmitted between cattle by natural service or AI. It establishes latent, life-lasting, and periodically reactivating infections in the host. It is also the most harmful herpes virus property, which makes the use of semen from BHV-1-seropositive bulls a major concern. Because of the disadvantages of BHV-1 detection in bovine semen by virus isolation in cell culture (Schultz et al., 1982 and Weiblen et al., 1992), the PCR has become an important diagnostic tool (Belak and Ballagi-Pordany, 1993; OIE, 2008). In addition to speed, specificity and sensitivity, PCR offers an additional advantage in the case of BHV-1 in that the present absolute requirement for good quality diagnostic samples is eliminated given the fact that only short sequences of target nucleic acid are necessary for detection (Moore et al., 2000). Several reports have shown that the detection of BHV-1 in bovine semen by PCR methods is relatively inexpensive, faster and even more sensitive compared to the virus isolation in cell culture (Van Engelenburg et al., 1993; Wiedmann et al., 1993; Vilcek et al., 1994; Xia et al., 1995; Masri et al., 1996; Wagter et al., 1996; Rocha et al., 1998 and Smits et al., 2000). Wang et al. (2007) were developed and standardized a real time PCR assay for detection of BoHV-1 in extended semen. Their assay was reported to be rapid, highly repeatable, purpose specific and more sensitive than virus isolation. Later on, in 2008, the OIE reported their real time PCR assay to be a prescribed test for detection of the virus in semen intended for international trade. The primers of Wang et al. (2007) were designed to target sequence of the glycoprotein B gene of BoHV-1 which is highly conserved gene in herpesviruses.

In this study we tried to take benefits of their primers but in conventional PCR assay and to compare results of both real-time and conventional PCR assays. After many trials of reaction optimization, a clear band of the expected size 96bp was steadily amplified in conventional PCR assay when DNA extracted from the BoHV-1 was used as template. Since this primer pair was already tested on total of 75 different strains of herpesviruses and was found to be highly specific and sensitive to BoHV-1 as reported by Wang et al. (2007); thereby, from a practical point of view there was no need to retest it again.

Infection of BoHV-1 usually occurs when semen passes down the male reproductive tract resulting in free virus in the seminal plasma (Straub, 1991 and Van Engelenburg et al., 1993). The artificially inoculated semen was reported to be a good model for the simulation of conditions found in the semen of naturally infected bulls. In this study, raw 
semen samples from BHV-1-negative bulls were used and experimentally spiked with the virus because naturally occurring BHV1-positive semen samples were not available.

A time-efficient protocol for nucleic acid extraction utilizing Chelex 100 has been developed to purify and isolate BHV-1 DNA and to overcome the inhibitory effects of bovine semen (Walsh et al., 1991 and Wiedmann et al., 1993). In this study, the method of Wiedmann et al. (1993) which was later on modified by Wang et al., 2007 for extraction of DNA from bovine semen and seminal plasma was used.

The analytical sensitivity of conventional PCR assay in comparison to real time PCR were determined by testing DNA extracted from $10 \mu \mathrm{l}$ of tenfold serial dilutions of BoHV-1 in ml of both MEM and spiked semen samples. It was also tested on DNA extracted from $10 \mu 1$ of seminal plasma obtained after centrifugation of the same serial dilutions of semen. The tenfold serial dilution started from $10^{7}$ to $10^{-4} \mathrm{TCID}_{50} / \mathrm{ml}$. Detection limits of real time PCR assays were $10^{-1} \mathrm{TCID}_{50} / \mathrm{ml}$ and $10^{2} \mathrm{TCID}_{50} / \mathrm{ml}$ when PCR performed on viral DNA extracted from tenfold dilutions of BoHV-1 in MEM and artificially spiked semen respectively. When seminal plasma of the same dilutions of spiked semen was used for DNA extraction, the PCR detection limit became $1 \mathrm{TCID}_{50} / \mathrm{ml}$. In conventional PCR, positive PCR products were detected down to $1 \mathrm{TCID}_{50} / \mathrm{ml}$ when PCR performed on viral DNA extracted from tenfold dilutions of BoHV-1 in MEM and artificially spiked semen respectively. When seminal plasma of the same dilutions of spiked semen was used for DNA extraction, the PCR detection limit was $10^{1} \mathrm{TCID}_{50} / \mathrm{ml}$. It is worthy to mention that all results of the PCR experiments were reproducible when repeated twice.

Comparison between detection limit of both real time and conventional PCR assays revealed that sensitivity of detection of BoHV-1 was better in conventional PCR assay performed on semen $1 \mathrm{TCID}_{50} / \mathrm{ml}$ versus $10^{2} \mathrm{TCID}_{50} / \mathrm{ml}$. On the contrary, the sensitivity of detection was better in real-time PCR assay when seminal plasma was used instead of semen $1 \mathrm{TCID}_{50} / \mathrm{ml}$ versus $10 \mathrm{TCID} \mathrm{D}_{50} / \mathrm{ml}$. Also, using seminal plasma instead of semen increased the sensitivity of the real-time PCR assay by two fold dilutions $1 \mathrm{TCID}_{50} / \mathrm{ml}$ versus $10^{2} \mathrm{TCID}_{50} / \mathrm{ml}$. Wang et al. (2007) reported the sensitivity of their real time assay for negative extended semen spiked with the virus to be $0.38 \mathrm{TCID}_{50} /$ reaction. The PCR assays reported by Yason et al. (1995), Masri et al. (1996), Santurde et al. (1996), Rocha et al. (1998) and Moore et al. (2000) were performed on artificially contaminated semen also. The authors reported their detection limit to be 1 TCID50/50 $\mu 1 ; 1$ TCID50/ml; 0.25-2.5 TCID T0 $_{50} / 0.5 \mathrm{ml} ; 10^{-3} \mathrm{TCID}_{50} / 50 \mu 1$ and 
$1 \mathrm{TCID}_{50} / 50 \mu 1$ of BoHV-1, respectively in semen which were similar to those achieved by virus isolation methods.

In conclusion, conventional PCR assay performed in this study provide a satisfactory results for detection of BoHV-1 in bovine semen in comparison to real time PCR and other reported PCR assays. Also, the use of seminal plasma instead of whole semen can be better alternative increasing the sensitivity of detection of real time PCR assay.

\section{REFERENCES}

Abd El-Hafeiz, Y.G.M.; Abou Gazia, K.A.A. and Ibrahim, I.G.A. (2010): Sero-prevalence of bovine viral diarrhea virus and bovine herpesvirus -1 infection in Egypt and their relation to brucellosis. Global Veterinaria 4(1): 1-5

Ackermann, M. and Wyler, R. (1984): The DNA of an IPV strain of bovid herpesvirus 1 in sacral ganglia during latency after intravaginal infection. Vet. Microbiol. 9: 53-63.

Amin, A.S. and Ibrahim, A.K. (1998): Detection of bovineherpes virus type 1 in semen using a rapid and sensitive polymerase chain reaction. Vet. Med. J. 46: 463-469.

Belak, S. and Ballagi-Pordany, A. (1993): Application of the polymerase chain reaction (PCR) in veterinary diagnostic virology. Vet. Res. Commun. 17: 55-72.

Chapman, M.S.; Lucas, M.H.; Hebert, C.N. and Goody, R.G. (1979): Survival of infectious bovine rhinotrachitis virus in stored bovine semen. Vet. Sci. Comm. 3: 137-139.

Dennett, D.P.; Barasa, J.Q. and Johnson, J.H. (1976): Infectious bovine rhinotracheitis virus: studies on the venereal carrier status range of cattle. Res. Vet. Sci. 20: 77-83.

Drew, T.W.; Hewitt-Taylor, C.; Watson, L. and Edward, S. (1987): Effect of storage conditions and culture technique on the isolation of infectious bovine rhinotracheitis virus from bovine semen. Veterinary Record 121: 547-548.

Elazhary, M.S.S.Y.; Lamothe, P.; Silim, A. and Roy, R.S. (1980): Bovine herpesvirus type-1 in the sperm of a bull from a herd with fertility problems. Can. Vet. J. 21: 336-339.

El-Kholy, A.A. (2005): Molecular and immunological detection of bovine herpesvirus-1 in clinical specimens. Egypt J. Immunol. 12: 125-136.

Gibbs, E.P. and Rweyemamu, M.M. (1977): Bovine herpesviruses. I. Bovine herpesvirus 1. Vet. Bull. 47: 317-343. 
Ibrahim, A.K.; Amin, A.S. and Awad, W.S. (2001): Evaluation of polymerase chain reaction and DNA hybridization assay as diagnostic tools for diagnosis of bovine herpes virus type-1 infection in dairy cows. J. Vet. Med. Ass. 61: 115-124.

Mahony, T.J. (2010): Bovine herpesvirus: What is missing from our understanding of the relationship between BoHV-1 and BoHV-5? The Veterinary journal, 184(2) 124-125.

Masri, S.A.; Olson, W.; Nguyen, P.T. and Deregt, D. (1996): Rapid detection of bovineherpesvirus 1 in the semen of infected bulls by a nested polymerase chain reaction. Can. J. Vet. Res. 60: 100-107.

Miller, J.M. (1991): The effects of IBR infection on reproductive function of cattle. Vet. Med. 86: 95-98.

Mohsen, A.Y.; El-Dobeigy, A.; Nakashly, S.A. and Mohamed, Z. (1980): Isolation and identification of IPV from local cattle and buffalo in Egypt. Vet. Med. Ass. 38: 45-53.

Moore, S.; Gunn, M. and Walls, D. (2000): A rapid and sensitive PCR based diagnostic assay to detect bovine herpesvirus 1 in routine diagnostic submissions. Veterinary Microbiology 75: 145-153.

Muylkens, B.; Thiry, J.; Kirten, P.; Schynts, F. and Thiry, E. (2007): Bovine herpesvirus 1 infection and infectious bovine rhinotracheitis. Vet. Res. 38: 181-209.

Office International des Epizooties, OIE, (2004): Infectious bovine rhinotracheitis/infectious pustular vulvovaginitis. In: Manual of Standards for Diagnostic Tests and Vaccines for Terrestrial Animal (Mammals, Birds and Bees), fifth ed, pp. 381-391.

Office International des Epizooties, OIE, (2008): Infectious bovine rhinotracheitis/infectious pustular vulvovaginitis. In: Manual of Standards for Diagnostic Tests and Vaccines for Terrestrial Animal (Mammals, Birds and Bees), fifth ed, pp. 752-767.

Pastoret, P.P.; Thirty, E.; Brochier, B.; Derboven, G. and Vindevogel, H. (1984): The role of latency in the epizootiology of infectious bovine rhinotracheitis. In: Wittmann, G., Gaskell, R., Rziha, H.-J. (Eds.), Latent Herpesvirus Infections in Veterinary Medicine. Martinus Nijhoff, The Hague, pp. 191-209.

Rocha, M.A.; Barbosa, E.F.; Guimaraes, S.E.F.; Neto, E.D. and Gouveia, A.M.G. (1998): A high sensitivity-nested PCR assay for BoHV-1 detection in semen of naturally infected bulls. Vet. Microbiol. 63: $1-11$. 
Santurde, G.; Da Silva, N.; Villares, R.; Tabares, E.; Solana, A.; Bautista, J.M. and Castro, J.M. (1996): Rapid and high sensitivity test for direct detection of bovine herpesvirus-1 genome in clinical samples. Veterinary Microbiology 49: 81-92.

Scicluna, M.T.; Caprioli, A.; Saralli, G.; Manna, G.; Barone, A.; Cersini, A.; Cardeti, G.; Condoleo, R.U. and Autorino, G.L. (2010): Should the domestic buffalo (Bubalus bubalis) be considered in the epidemiology of Bovine Herpesvirus 1 infection?, Veterinary Microbiology [Epub ahead of print].

Schultz, R.D.; Adams, L.S.; Letchworth, G.; Sheffy, B.E.; Manning, B. and Bean, B. (1982): A method to test large numbers of bovine semen samples for viral contamination and results of a study using this method. Theriogenology 17: 115-123.

Smits, C.B.; Van Maanen, C.; Glas, R.D.; De Gee, A.L.W.; Dijkstrab, T.; Van Oirschot, J.T. and Rijsewijk, F.A.M. (2000): Comparison of three polymerase chain reaction methods for routine detection of bovine herpesvirus 1 DNA in fresh bull semen. J. Virol. Methods 85: 65-73.

Straub, O.C. (1991): BHV1 infections: relevance and spread in Europe. In: Comparative Immunology and Microbiology of Infectious Diseases, Vol. 14: pp. 175-186.

Thiry, E.; Saliki, J.; Pastoret, P.P.; Lambert, A.F. and Ligot, A. (1984): Failure to demonstrate infectious bovine rhinotracheitis virus reactivation in parturient cows. Vet. Rec. 8: 248-249.

Thiry, J.; Keuser, V.; Muylkens, B.; Meurens, F.; Gogev, S.; Vanderplasschen, A. and Thiry, E. (2006): Ruminant alphaherpesviruses related to bovine herpesvirus 1. Vet. Res. 37: 169-190.

Van Engelenburge, F.A.C.; Maes, R.K.; Van Oirschot, J.T. and Rijsewijk, F.A.M. (1993): Development of a rapid and sensitive polymerase chain reaction assay for detection of bovine herpesvirus type 1 in bovine serum. J. Clin. Microbiol. 31: 3129-3135.

Van Engelenburge, F.A.C.; Van Schie, F.W.; Rijsewijk, F.A.M. and Van Oirschot, J.T. (1995): Excretion of bovine herpesvirus 1 in semen is detected much longer by PCR than by virus isolation. J. Clin. Microbiol. 33: 308-312.

Vilcek, S.; Nettleton, P.F.; Herring, J.A. and Herring, A.J. (1994): Rapid detection of bovine herpesvirus 1 (BoHV-1) using the polymerase chain reaction. Vet. Microbiol. 42: 53-64. 
Wagter, L.H.A.; Glas, R.D.; Bleumink-Pluym, N.; Engelenburg, F.A.C.; Rijsewijk, F.A.M. and Houwers, D.J. (1996): A polymerase chain reaction (PCR) assay for the detection of bovine herpesvirus 1 (BHV1) in selectively digested whole bovine semen. Vet. Res. Comm. 20: 401-408.

Walsh, S.P.; Metzger, D.A. and Higuchi, R. (1991): Chelex 100 as a method for PCR-based typing from forensic material. Biotechniques 10: 506-513.

Wang, J.; O'Keefe, J.; Della Orr, D.; Loth, L.; Banks, M.; Wakeley, P.; West, D.; Card, R.; Ibata, G.; Van Maanenc, K.; Thoren, P.; Isaksson, M. and Pierre Kerkhofs, P. (2007): Validation of a realtime PCR assay for the detection of bovine herpesvirus 1 in bovine semen. J. Virol. Methods 144: 103-108.

Weiblen, R.; Kreutz, L.; Canaborro, T.F.; Schuch, L.C. and Rebelatto, M.C. (1992): Isolation of bovine herpesvirus 1 from preputial swabs and semen of bulls with balanoposthitis. Journal of Veterinary Diagnostic Investigation 4: 341-343.

Wiedmann, M.; Brandon, R.; Wagner, P.; Dubovi, E.J. and Batt, C.A. (1993): Detection of bovine herpesvirus-1 in bovine semen by a nested PCR assay. J.Virol.Methods 44: 129-140.

Wyler, R.; Engles, M. and Schwyzer, M. (1989): Infectious bovine rhinotracheitis /vulvovaginitis (BoHV-1). In: Wittman, G. (Ed.), Herpesvirus Disease of Cattle, Horses and Pigs. Kluwer Academic, Boston, USA, pp. 1-72.

Xia, J.Q.; Yason, C.V. and Kibenge, F.S.B. (1995): Comparison of dod-blot hybridization, polymerase chain reaction and virus isolation for the detection of bovine herpesvirus 1 (BHV1) in arti®cially infected bovine semen. Can. J. Vet. Res. 59: 102-109.

Yason, C.V.; Harris, L.M.; McKenna, P.K.; Wadowska, D. and Kibenge, S.B. (1995): Establishment of conditions for the detection of bovine herpesvirus 1 by the polymerase chain reaction using primers from the thymidine kinase region. Can. J. Vet. Res. 59: 94-101. 